\title{
Free radical-mediated acetaldehyde formation by model reactions of dietary components: effects of meat, wine, cooking oil and coffee
}

\author{
Hiroshi Kasai ${ }^{*}$ (D) and Kazuaki Kawai ${ }^{1,2}$
}

\begin{abstract}
Background: Alcohol consumption and the ingestion of red meat and oxidized cooking oil are risk factors of gastric and colorectal cancers. We reported that acetaldehyde (AcAld) is generated from Heme/Mb/Meat-Linoleate$\mathrm{EtOH}$ model reaction mixtures, and thus could be a new plausible mechanism for the carcinogenesis (Kasai and Kawai, ACS Omega, 2021).

Results: In this study, we investigated the effects of wine and coffee, in addition to meat components, on this reaction. Depending on the conditions, such as $\mathrm{pH}$, reaction time and choice of free hemin, myoglobin (Mb), as well as meat extracts (raw meat, baked meat, salami), wine and coffee enhanced AcAld formation. Polyphenols in red wine and coffee may stimulate AcAld formation by acting as pro-oxidants in the presence of Heme/Mb/Meat. In a model reaction of $\mathrm{Mb}+\mathrm{EtOH}+\mathrm{H}_{2} \mathrm{O}_{2}$, we observed time-dependent AcAld formation. In support of these in vitro data, after the consumption of a red meat-rich diet with red wine, the fecal AcAld level significantly increased as compared to the levels associated with a diet of fish + wine, or red meat without alcohol.

Conclusions: These results suggested that AcAld generation from dietary components may be an important mechanism of gastrointestinal tract carcinogenesis.

Keywords: Acetaldehyde, Gastric cancer, Colorectal cancer, Heme, Myoglobin, Linoleate, Polyphenol, Meat, Wine, Coffee
\end{abstract}

\section{Introduction}

Epidemiological studies are a powerful method to identify the causes of cancer. Alcohol drinking and the consumption of red meat, especially processed meat, are risk factors of gastric and colorectal cancers, as revealed by epidemiological studies [1-4]. Fried foods and reuse of cooking oil also increase the incidence of these cancers [5-7]. The most frequent mutation in the p53

\footnotetext{
* Correspondence: h-kasai@med.uoeh-u.ac.jp

${ }^{1}$ Department of Environmental Oncology, Institute of Industrial Ecological Sciences, University of Occupational and Environmental Health, 1-1 Iseigaoka, Yahatanishi-ku, Fukuoka 807-8555 Kitakyushu, Japan

Full list of author information is available at the end of the article
}

tumor suppressor gene observed in these cancers is $\mathrm{GC} \rightarrow \mathrm{AT}$ in specific positions with $\mathrm{GpC}$ sequences, which are often methylated [8], and the characteristics of the mutation spectrum and the hot spots are similar to those found in the p53 gene, induced by AcAld in a yeast functional assay system $[9,10]$. Based on this information from epidemiological and genomic studies, it is also important to clarify the carcinogenesis mechanisms by a chemical approach [11]. After extensive studies focusing on AcAld, we found its efficient formation in model reactions containing three components of these risk factors, Heme/Mb/Meat, linoleate and alcohol, but

C C The Author(s). 2021 Open Access This article is licensed under a Creative Commons Attribution 4.0 International License, which permits use, sharing, adaptation, distribution and reproduction in any medium or format, as long as you give appropriate credit to the original author(s) and the source, provide a link to the Creative Commons licence, and indicate if changes were made. The images or other third party material in this article are included in the article's Creative Commons licence, unless indicated otherwise in a credit line to the material. If material is not included in the article's Creative Commons licence and your intended use is not permitted by statutory regulation or exceeds the permitted use, you will need to obtain permission directly from the copyright holder. To view a copy of this licence, visit http://creativecommons.org/licenses/by/4.0/ The Creative Commons Public Domain Dedication waiver (http://creativecommons.org/publicdomain/zero/1.0/) applies to the data made available in this article, unless otherwise stated in a credit line to the data. 
not by the combinations of any two [12]. As a mechanism, linoleate hydroperoxide formation and decomposition in the presence of myoglobin (or heme) to generate an $\mathrm{OH}$ radical seem to be involved in the ethanol to acetaldehyde conversion (Scheme). This may represent a new plausible mechanism of gastric and colorectal carcinogenesis.

AcAld is an environmental mutagen and considerable amounts are present in ordinary foods and beverages [13]. It is a human carcinogen (IARC, group 1), especially in relation to alcohol consumption [14]. Alcohol is metabolized to AcAld by alcohol dehydrogenase (ADH) enzymes, and then to acetic acid by aldehyde dehydrogenase (ALDH). High incidences of oral, esophageal, stomach and colon cancers have been observed in ALDH-deficient subjects [1]. In relation to red meat intake, N-nitroso compounds, such as N-nitroso-glucosylglycine, and aldehydic compounds, such as 4-hydroxy-2nonenal and malonaldehyde, generated by heme-induced lipid peroxidation, have been suggested as possible carcinogenesis mechanisms [15], but the role of AcAld has not been described so far. In this study, we investigated the effects of red wine and coffee on the formation of AcAld in the model reactions, because meat, wine and coffee are often consumed together in ordinary daily dietary habits. Various model reactions were examined at $\mathrm{pH} 4.5$ and $\mathrm{pH} 7.4$, as representative $\mathrm{pH}$ values of the gastric juices of normal and high-risk groups, respectively (further details in the Discussion). The experiments at $\mathrm{pH} 7.4$ also correspond to the $\mathrm{pH}$ of the colonic contents of colon cancer high-risk groups. As an initial condition of digestion in the healthy stomach, the reaction of meat + wine + coffee was examined at $\mathrm{pH}$ 3.5. We also investigated whether various diet combinations affect the fecal AcAld levels, in relation to colorectal carcinogenesis.

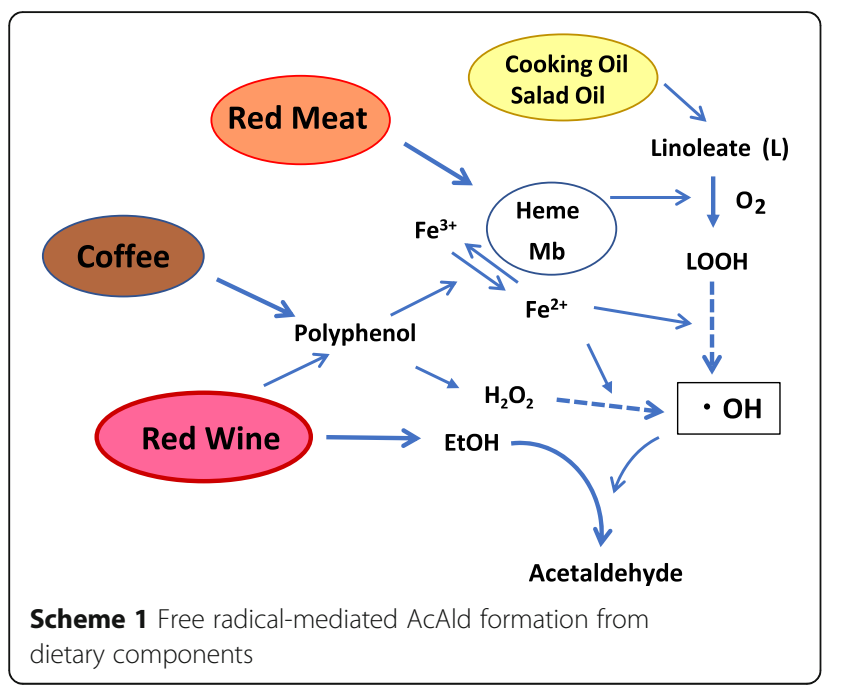

\section{Experimental section Materials}

Hemin was purchased from Sigma-Aldrich Chemical Co., USA. Tween 20 was obtained from ICN Biochemicals, Inc., USA. Horse myoglobin $(\mathrm{Mb})$ was procured from SERVA Electrophoresis GmbH, Germany. Methyl linoleate (MLA) was purchased from Tokyo Chemical Industry Co., Ltd. Japan. 2,4-Dinitrophenylhydrazine (DNPH), ethanol (99.5\%), and hydrogen peroxide (30\%) were obtained from Wako Pure Chemical Industries, Ltd., Japan. Beef, salami, red wine ( $13.5 \%$ alcohol), and instant coffee were purchased in a grocery store.

\section{Preparation of meat homogenates}

Meat was baked in a pan without cooking oil until it was browned, as in the usual preparation. Portions $(0.7 \mathrm{~g})$ of raw and baked meat, or salami were cut into small pieces and homogenized in water $(5 \mathrm{ml})$ containing Tween $20(10 \mu l, 0.2 \%)$, with a Polytron PT10-35 (Kinematica, Switzerland) for $30 \mathrm{~s}$ at room temperature. The homogenates were divided into $500 \mu \mathrm{l}$ aliquots in Eppendorf tubes $(2 \mathrm{ml})$ and kept in a freezer at $-20{ }^{\circ} \mathrm{C}$ until use.

\section{Reaction of hemin-MLA-EtOH/Wine}

Hemin was dissolved in $20 \mathrm{mM} \mathrm{NaOH}(2.17 \mathrm{mg} / \mathrm{ml})$. For the ethanol reaction mixture, the hemin solution (23 $\mu \mathrm{l}$; final concentration, $160 \mu \mathrm{M}$ ), ethyl acetate $(50 \mu \mathrm{l})$, MLA $(20 \mu \mathrm{l})$, ethanol $(50 \mu \mathrm{l})$, and $2 \mathrm{M}$ sodium acetate buffer $(40 \mu \mathrm{l}, \mathrm{pH} 4.5)$, and water $(360 \mu \mathrm{L})$ were mixed in an Eppendorf tube $(2 \mathrm{ml})$. The tube was capped and vigorously shaken to produce a homogeneous emulsion at $37^{\circ} \mathrm{C}$. The reaction was continued for $4 \mathrm{~h}$. For the reaction at $\mathrm{pH} 7.4,2 \mathrm{M}$ phosphate buffer (pH 7.4) was used instead of the acetate buffer. For the wine reaction mixture, the hemin solution $(23 \mu \mathrm{l}$; final concentration, $160 \mu \mathrm{M})$, ethyl acetate $(50 \mu \mathrm{l})$, MLA $(20 \mu \mathrm{l})$, wine $(369 \mu \mathrm{l}), 2 \mathrm{M}$ buffer $(40 \mu \mathrm{l})$, and water (41 $\mu \mathrm{L})$ were mixed.

\section{Reaction of meat-MLA-EtOH/Wine}

MLA (20 $\mu \mathrm{l}), 2 \mathrm{M}$ phosphate buffer (pH 7.4) $(55 \mu \mathrm{l})$, and ethanol $(23 \mu \mathrm{l}$, plus $147 \mu \mathrm{L}$ water) or wine $(170 \mu \mathrm{L})$ were added to the meat homogenates $(500 \mu \mathrm{l})$ in an Eppendorf tube $(2 \mathrm{ml})$. The tube was capped and vigorously shaken to produce a homogeneous emulsion at $37^{\circ} \mathrm{C}$. In these reactions, the approximate heme concentration was $50 \mu \mathrm{M}$, based on the assumption that meats contain $1 \% \mathrm{Mb}$.

\section{Reaction of baked meat-wine-coffee}

Coffee was prepared by dissolving $2 \mathrm{~g}$ of instant coffee powder in $140 \mathrm{~mL}$ of hot water. Baked meat homogenate (300 $\mu \mathrm{L}, 50 \mu \mathrm{M}$ as heme), red wine $(150 \mu \mathrm{L})$ and coffee 
$(150 \mu \mathrm{L})$ were mixed with $1 \mathrm{M} \mathrm{NaH}_{2} \mathrm{PO}_{4}(300 \mu \mathrm{L})$, and the final $\mathrm{pH}$ was adjusted to 3.5 by adding $2 \mathrm{~N} \mathrm{HCl}$. The tube was capped and vigorously shaken to produce a homogeneous emulsion at $37^{\circ} \mathrm{C}$. For the reaction of two components (baked meat, wine), water $(150 \mu \mathrm{L})$ was added instead of coffee. For the reaction without meat and coffee, $450 \mu \mathrm{L}$ of water was added instead.

\section{Reaction of $\mathrm{Mb}-\mathrm{EtOH}-\mathrm{H}_{2} \mathrm{O}_{2}$}

A $500 \mu \mathrm{l}$ aliquot of the $\mathrm{Mb}$ solution $(1.3 \mathrm{mg} / \mathrm{ml}$ water plus $2 \mu \mathrm{l}$ Tween 20) (final concentration, $60 \mu \mathrm{M}$ ) was mixed with ethanol $(50 \mu \mathrm{l}), \mathrm{H}_{2} \mathrm{O}_{2}(2.7 \mu \mathrm{L}$, final concentration $40 \mathrm{mM}$ ), and $2 \mathrm{M}$ phosphate buffer $(\mathrm{pH} 7.4)$ $(55 \mu \mathrm{l})$ in an Eppendorf tube $(2 \mathrm{ml})$. The tube was capped and incubated at $37^{\circ} \mathrm{C}$.

\section{Analysis of AcAld in the reaction mixture}

AcAld was analyzed by the previously described method [12]. Briefly, after centrifugation of the emulsion reaction mixture, $10 \mu \mathrm{l}$ of the supernatant (or water for blank) was mixed with $100 \mu \mathrm{l}$ of $0.2 \mathrm{M}$ sodium acetate ( $\mathrm{pH} 4.5$ ) and $100 \mu \mathrm{l}$ of 2,4-dinitrophenylhydrazine solution in acetonitrile $(1.25 \mathrm{mg} / \mathrm{ml})$, and reacted for $3 \mathrm{~min}$ at room temperature $\left(23^{\circ} \mathrm{C}\right)$. After centrifugation, a $50 \mu$ l portion of the supernatant was immediately injected into an HPLC column (CAPCELL PAK C18 MG II, $3 \mu \mathrm{m}, 4.6$ $\mathrm{mm} \times 150 \mathrm{~mm}$, Shiseido Fine Chemicals, Japan) connected with a photodiode array UV detector (HewlettPackard 1100 HPLC Detection System). The following linear gradient of acetonitrile concentration in $10 \mathrm{mM}$ ammonium formate was used: $0-15 \mathrm{~min}, 50-100 \%$; $15-$ $20 \mathrm{~min}, 100 \%$. The elution speed was $0.8 \mathrm{ml} / \mathrm{min}$. The blank value was subtracted from each analysis value of the reaction mixture. The AcAld concentration was determined based on the calibration curve.

\section{LC/MS}

The AcAld-DNPH from feces was identified by HPLC coupled to a hybrid quadrupole-Orbitrap mass spectrometer (Q Exactive Focus, Thermo Fisher Scientific, Waltham, MA) with negative-ion ESI-MS. The sample separation was achieved on an Acclaim 120 C18 column $(2.1 \mathrm{~mm} \times 50 \mathrm{~mm}, 3 \mu \mathrm{m}$, Thermo Fisher Scientific, Waltham, MA) with a flow rate of $0.3 \mathrm{ml} / \mathrm{min}$ and a column temperature of $30{ }^{\circ} \mathrm{C}$. Mobile phase A was $10 \mathrm{mM}$ ammonium formate and mobile phase $\mathrm{B}$ was acetonitrile. The percentage of solvent $\mathrm{B}$ changed as follows: 02 min, 40\%; 2-10 min, 40-90\% (linear gradient). The injection volumes for the measurements were $5 \mu \mathrm{l}$. The AcAld-DNPH $\left(\mathrm{C}_{8} \mathrm{H}_{8} \mathrm{~N}_{4} \mathrm{O}_{4}\right)$ was identified using the extracted ion chromatogram of $m / z 223.04728$ [M-H] ${ }^{-}$.

\section{Analysis of AcAld in feces}

A subject (male, age 73 at the time of sample collection, Asian flusher with low ALDH, body weight $51 \mathrm{~kg}$ ) ingested three different diets: (1) meat plus wine, (2) fish plus wine, and (3) meat plus non-alcohol beer, for three consecutive days. In diet-1, the total amounts of meat (salami, sausage, etc., at breakfast, and red beef at lunch and dinner) and red wine were 200-250 g and 120-150 $\mathrm{mL}$ per day, respectively. Red wine was consumed during dinner. During the meat challenge and other diet periods, moderate amounts of bread, rice, yoghurt, vegetables, fruits, tea and coffee, etc., were ingested as usual. In diet-2, meat was replaced by white fish or chicken tenders, and the alcohol (red wine) consumption was the same as in diet-1. Diet-3 was the same as diet- 1 , except that the wine was replaced by non-alcoholic beer. On the second, third, and fourth days from the start of each diet, fecal samples were collected from 3 to 4 different positions in the morning feces, and immediately frozen and kept at $-20{ }^{\circ} \mathrm{C}$. For the AcAld analysis, an 80 $\mu \mathrm{L}$ portion of the feces was dispersed within a cold mixture of DNPH solution $(800 \mu \mathrm{L})$ and acetate buffer $(800$ $\mu \mathrm{L}$ ) to make emulsions during $3 \mathrm{~min}$ of vigorous mixing and occasional crushing of feces by toothpicks. The reaction mixture was kept at $5{ }^{\circ} \mathrm{C}$ for $20 \mathrm{~min}$ and then centrifuged, and a $50 \mu \mathrm{L}$ portion of the supernatant was injected into the HPLC apparatus. Conditions for HPLC were the same as above. The study was approved by the University of Occupational and Environmental Health Ethics Committee (R3-005). Written informed consent was obtained from the subject.

\section{Results}

Effect of red wine on AcAld formation in model reactions Model systems of dietary components, containing meat/ $\mathrm{Mb} /$ hemin, MLA, and $\mathrm{EtOH} /$ wine, were reacted in an emulsion at $\mathrm{pH} 7.4$ or 4.5. When the Hemin-MLA$\mathrm{EtOH}-$ and Hemin-MLA-Wine-reactions in emulsion were compared at $\mathrm{pH}$ 7.4, higher AcAld generation was observed in the mixture with wine during the initial $2 \mathrm{~h}$ as compared to those with ethanol (Fig. 1b). At $4 \mathrm{~h}$, slight inhibition was observed. The stimulation of AcAld generation by wine was not observed at $\mathrm{pH} 4.5$ (Fig. 1a). At time zero, considerable amounts of AcAld (70-100 $\mu \mathrm{M})$ were detected, because wine itself contains AcAld.

In the salami-containing reaction, AcAld formation was strongly stimulated by wine as compared to EtOH at $\mathrm{pH}$ 7.4 (Fig. 2). When the reaction with raw meat was examined, wine inhibited AcAld formation, especially in the latter period (Fig. 3). In the reaction of baked meat with wine and coffee, AcAld formation was stimulated at the stomach condition of pH 3.5 (Fig. 4), without MLA. In a model reaction of $\mathrm{Mb}+\mathrm{EtOH}+\mathrm{H}_{2} \mathrm{O}_{2}$ ( $\mathrm{pH}$ 7.4), time-dependent AcAld formation was observed (Fig. 5). 


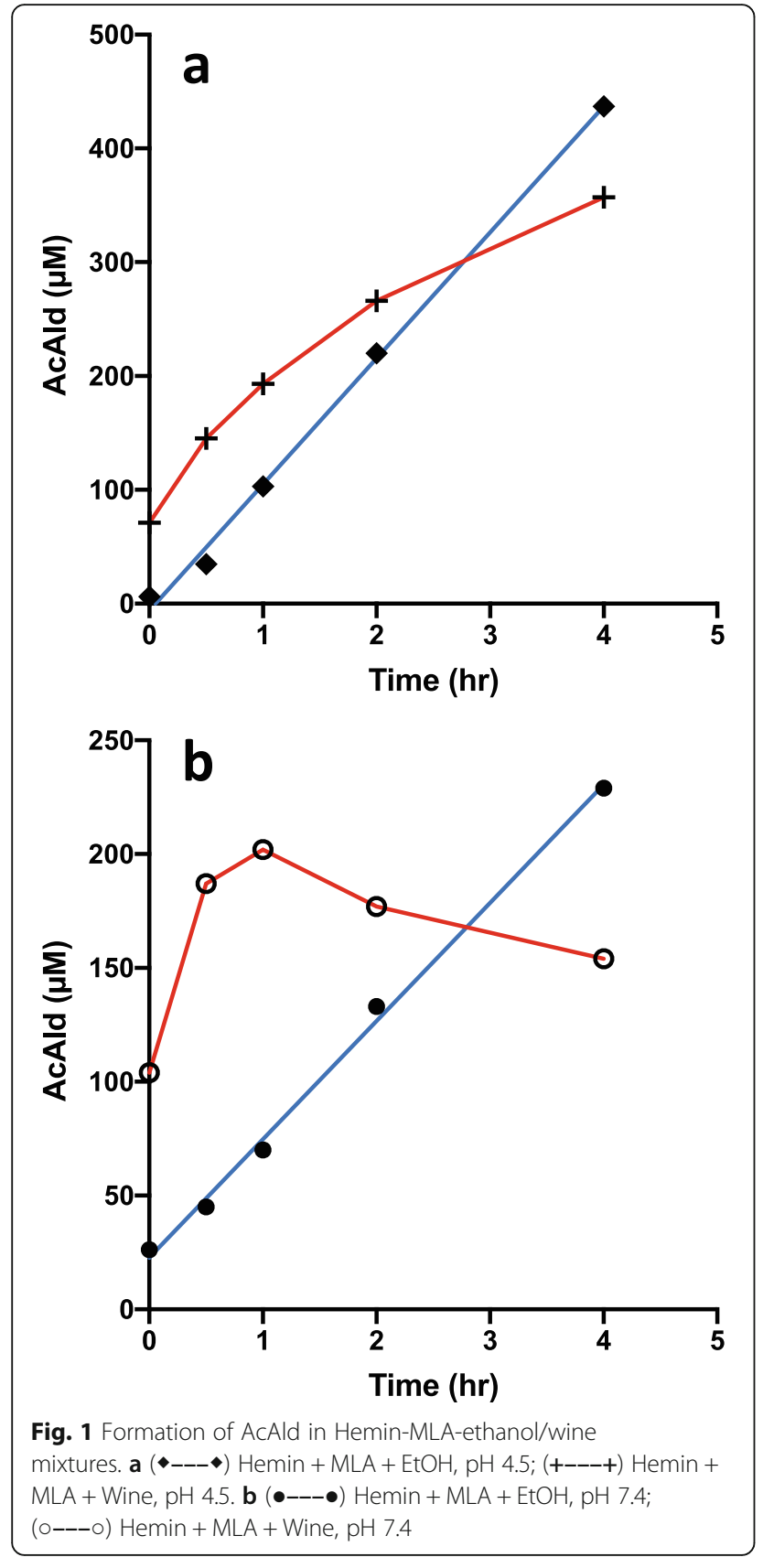

In this reaction, background levels of AcAld were detected at time 0 and in the control experiments, mainly due to the presence of trace amounts of AcAld in the ethanol reagent.

Increase of fecal AcAld after red meat plus wine diet

The chromatograms of the analysis of AcAld in feces are shown in Fig. 6. The hydrazone products produced by the reaction of AcAld with DNPH were eluted as a mixture of E- and Z-stereoisomers, as detected by the UV absorbance at $360 \mathrm{~nm}$, and quantified against the standard. The retention time and UV spectrum of the product

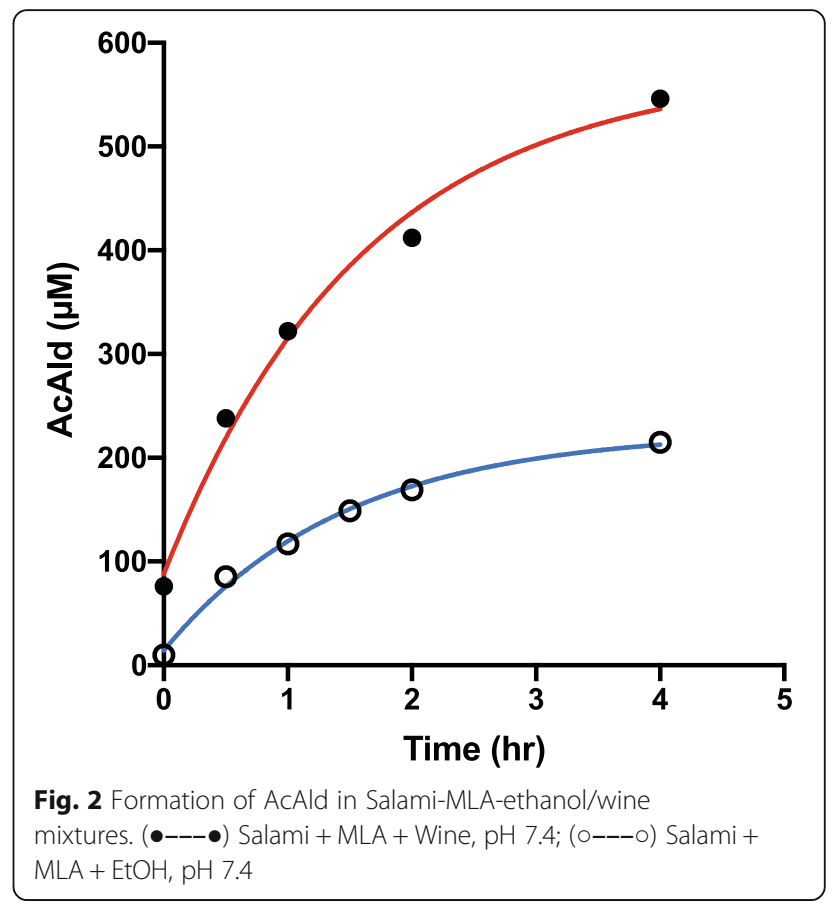

in HPLC were identical to those of the standard AcAld treated with DNPH. The identity of the AcAld-DNPH derivative was further confirmed by LC-MS (Fig. 7).

After the consumption of the red meat-rich diet with wine, the fecal AcAld level significantly increased, as compared to the diets of fish + wine, or red meat without alcohol (Fig. 8). Although the AcAld level did not reach the mutagenic concentration, the results suggest that the

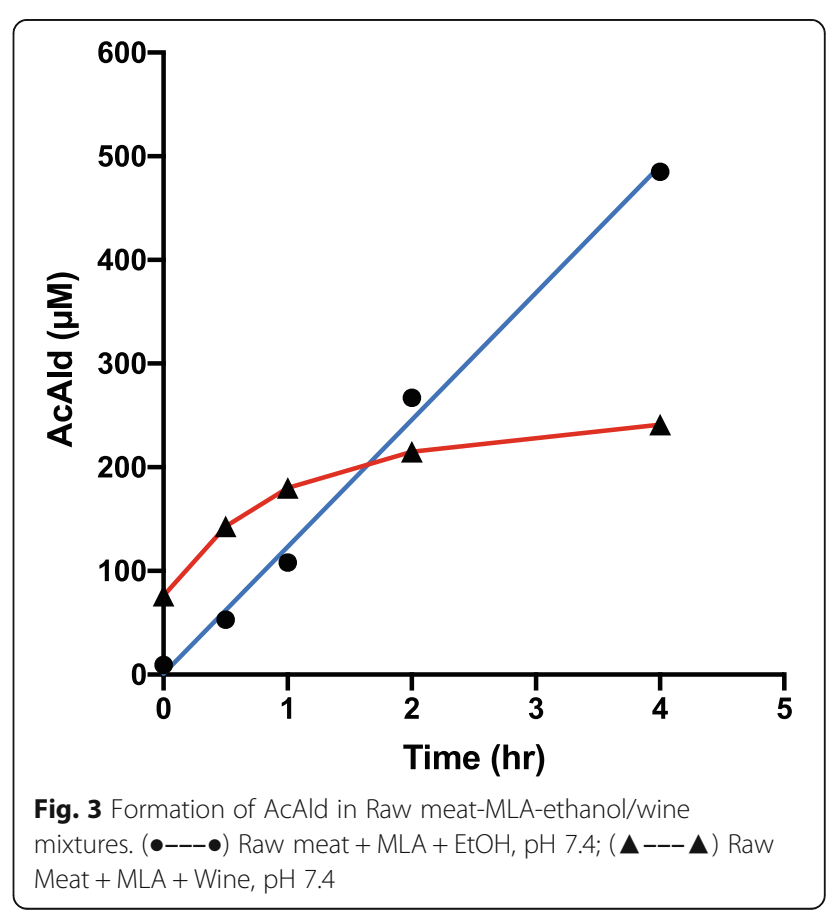




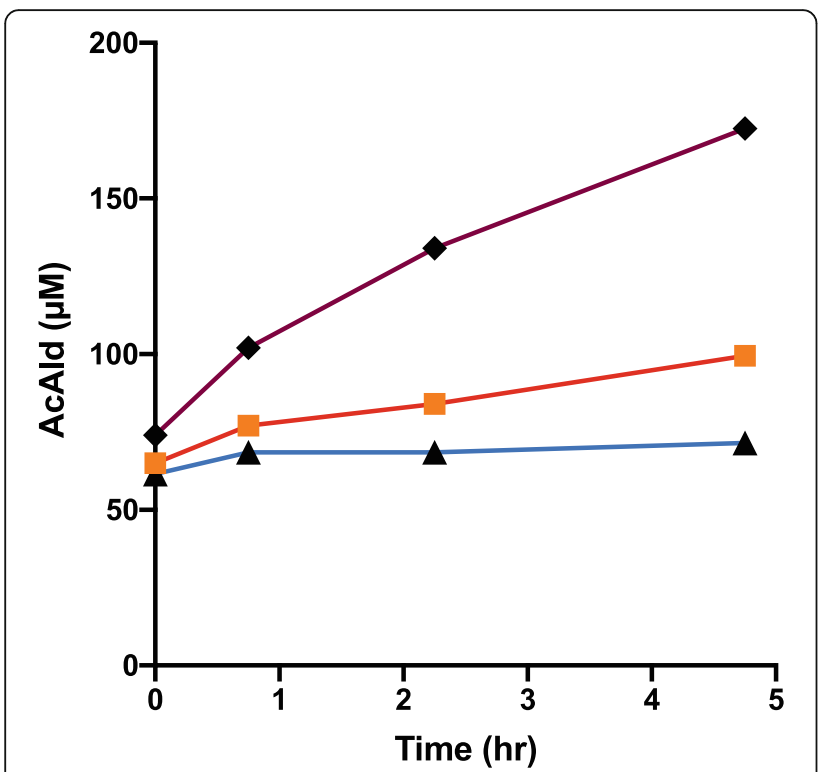

Fig. 4 Formation of AcAld in Baked meat-Wine-Coffee mixtures.

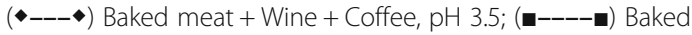
meat + Wine, $\mathrm{pH} 3.5$; $(\boldsymbol{\Delta}---\boldsymbol{\Delta})$ Wine, $\mathrm{pH} 3.5$

AcAld enhancing effect observed in the model reaction could occur in vivo by the combination of red meat and wine.

\section{Discussion}

Many papers have reported that wine has cancerpreventive effects, due to the high concentration of polyphenols [16]. However, heavy drinkers of wine have high incidences of gastric cancer, as revealed by

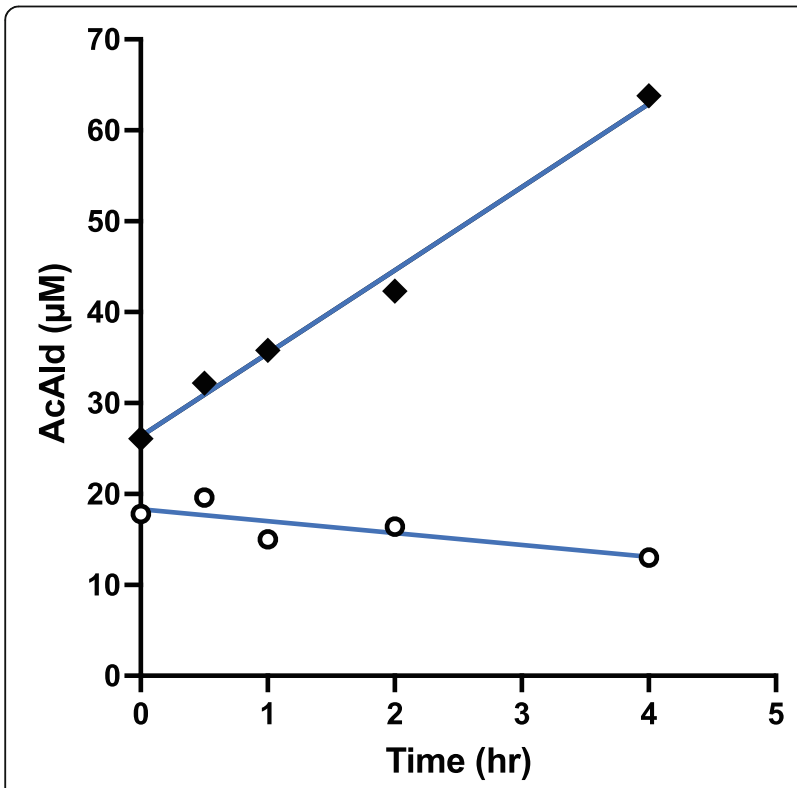

Fig. 5 Formation of $\mathrm{AcAld}$ in $\mathrm{Mb}+\mathrm{EtOH}+\mathrm{H}_{2} \mathrm{O}_{2}$ mixtures ( $\mathrm{pH}$ 7.4). (•---) With $\mathrm{H}_{2} \mathrm{O}_{2}$; ( epidemiological studies in France, Portugal and Paraguay [17-19]. Prospective studies in large populations demonstrated that persons who preferred wine were more likely to develop colon cancer [20, 21]. Processed meats such as sausage, ham and salami are suspected to be higher risk factors for both gastric and colon cancers than red meat [2-4]. Other epidemiological studies suggested that the co-consumption of alcohol and red meat synergistically increases the colon cancer risk [22, 23]. The effect of coffee consumption on cancer risk was also extensively studied; however, the results were controversial [24]. Coffee is a risk factor for gastric cancer [25] and colorectal cancer [26]. Because wine, meat, coffee, etc. are often consumed together in western dietary habits, it may be difficult to distinguish the effect of each individual factor by epidemiological methods [27], or to assess their combined effects on cancer induction. Our results support the hypothesis that wine and coffee enhance the gastric and colorectal carcinogenesis promoted by red meat.

In normal subjects, the stomach fluid $\mathrm{pH}$ range is $1.1-$ 2.1 under fasted conditions, and 1.0-5.6 after a meal, as shown in Fig. 9 [28, 29]. On the other hand, in the high risk gastric cancer groups, such as achlorhydric patients, and especially those with pernicious anemia or hypogammaglobulinaemia, or subjects with gastric ulcers associated with $H$. pylori infection, the stomach fluid approaches a neutral pH (4.0-8.3) [30-32]. The gastric cancer risk is significantly enhanced by the interaction of red meat consumption and $H$. pylori infection (presumably due to high gastric $\mathrm{pH}$ ) [33, 34]. The $\mathrm{pH}$ values of fasted and postprandial gastric juices in high-risk groups seem to be similar, as determined previously [28]. Differences in fecal pH (5.5-7.6 versus 6.4-8.9) were also observed between the control and colon cancer high risk groups (Fig. 10) [35]. In the present study we chose $\mathrm{pH} 3.5,4.5$ and 7.4 as representative $\mathrm{pH}$ values for the model reactions, considering the $\mathrm{pH}$ values of the normal and high-risk groups. Enhanced AcAld formation was observed especially at $\mathrm{pH} 7.4$ in the heminMLA-wine and salami-MLA-wine reactions, as compared to the ethanol-containing reaction. The potent enhancing effect at $\mathrm{pH} 7.4$ may be due to the generation of $\mathrm{H}_{2} \mathrm{O}_{2}$ by the autooxidation of wine polyphenols at neutral $\mathrm{pH}$, as in many other plant polyphenols [36]. The time-dependent formation of AcAld in a model reaction of $\mathrm{H}_{2} \mathrm{O}_{2}, \mathrm{Mb}$ and EtOH at $\mathrm{pH} 7.4$ supported this mechanism (Fig. 5) $\mathrm{H}_{2} \mathrm{O}_{2}$ production may also occur in the colon, because the colorectal mucosal surface is usually aerobic due to oxygen diffusion from the colorectal submucosa [37]. The polyphenols in red wine and coffee also stimulated AcAld formation at $\mathrm{pH} 3.5$ with baked meat. This may be due to the generation of $\mathrm{H}_{2} \mathrm{O}_{2}$ with the concomitant reduction of $\mathrm{MetMb}\left(\mathrm{Fe}^{3+}\right)$ to $\mathrm{Mb}\left(\mathrm{Fe}^{2+}\right)$, 


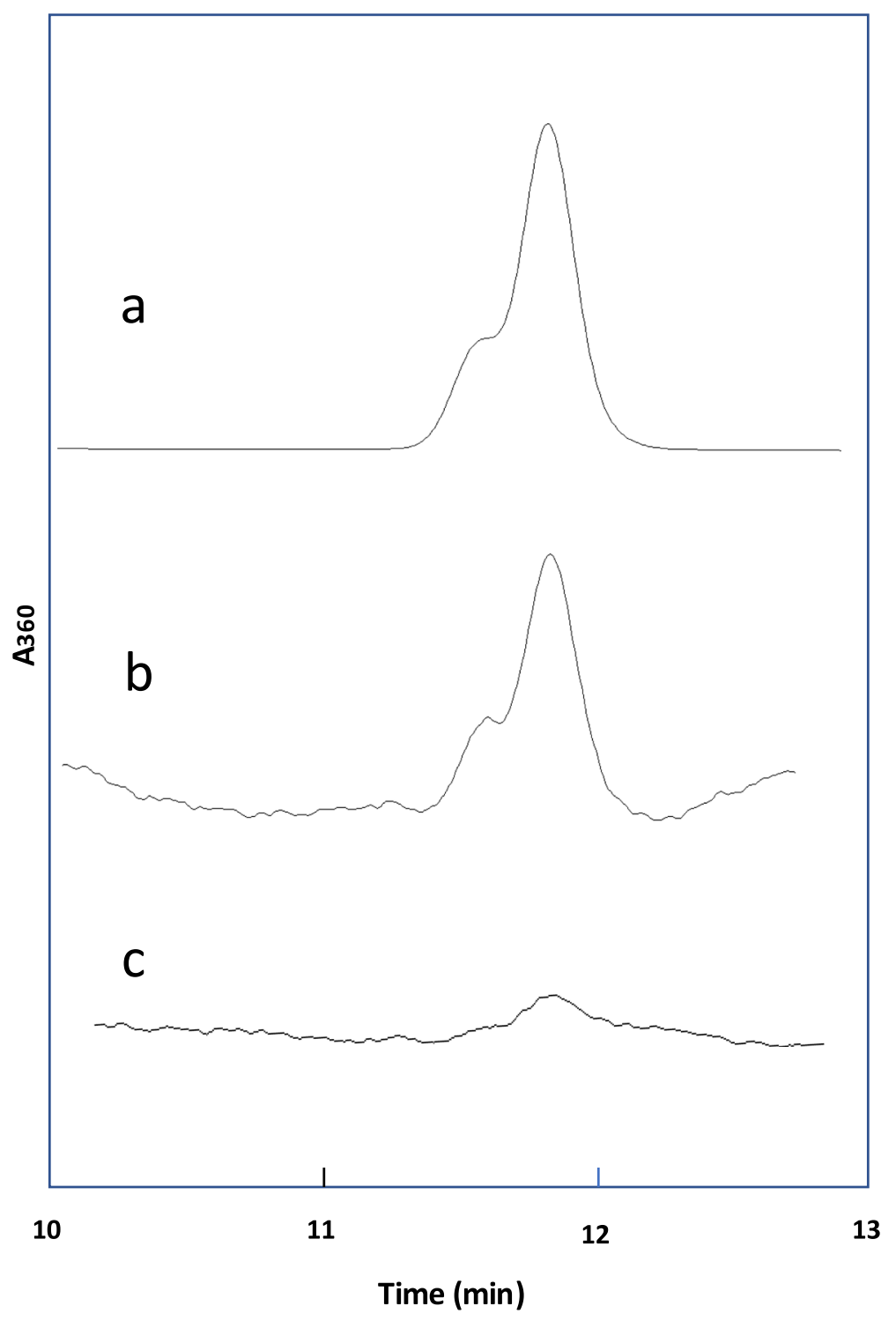

Fig. $6 \mathrm{HPLC}$ analysis of AcAld in feces derivatized with 2,4-dinitrophenyl hydrazine (DNPH). a Standard, $\mathbf{b}$ feces reaction mixture, $\mathbf{c}$ blank

which would enhance OH-radical generation and AcAld formation (Scheme). In the present study, the effect of coffee was examined at a normal gastric $\mathrm{pH}$ (3.5). It is highly possible that the enhanced AcAld formation by coffee consumption may also occur at neutral $\mathrm{pH}$. Most orally ingested polyphenols (90-95\%) reportedly reach the colon [38]. Therefore, the high AcAld formation in the meat- and heme-reactions with wine or coffee may be related to both gastric and colorectal carcinogenesis.

In a previous study, we found that baked meat has lower AcAld forming activity than raw meat and salami, with MLA and ethanol at $\mathrm{pH}$ 7.4. In this study, coffee enhanced AcAld formation in the mixture of baked meat and red wine at $\mathrm{pH}$ 3.5. Even with low concentrations of baked meat homogenates, red wine, and coffee, the
AcAld level increased to $170 \mu \mathrm{M}$ in $5 \mathrm{~h}$ (Fig. 4). The amounts of meat and wine in this model reaction correspond to $24 \mathrm{~g}$ meat and $83 \mathrm{ml}$ each of wine and coffee, if the gastric digestion volume is tentatively $500 \mathrm{ml}$ and the $\mathrm{Mb}$ content in meat is $1 \%$. Therefore, the observed AcAld formation in the reaction under-estimated the actual dietary situations, because usually the amounts of meat, wine and coffee in the diet are much higher. In the salami + wine experiments, where the AcAld concentration reached $540 \mu \mathrm{M}$ (Fig. 2), the amounts of salami and wine corresponded to $50 \mathrm{~g}$ and $120 \mathrm{ml}$ per $500 \mathrm{ml}$, respectively.

AcAld has been detected in human feces by GCMS, as a potential diagnostic tool for gastrointestinal diseases [39]. Urinary volatile organic compounds including 


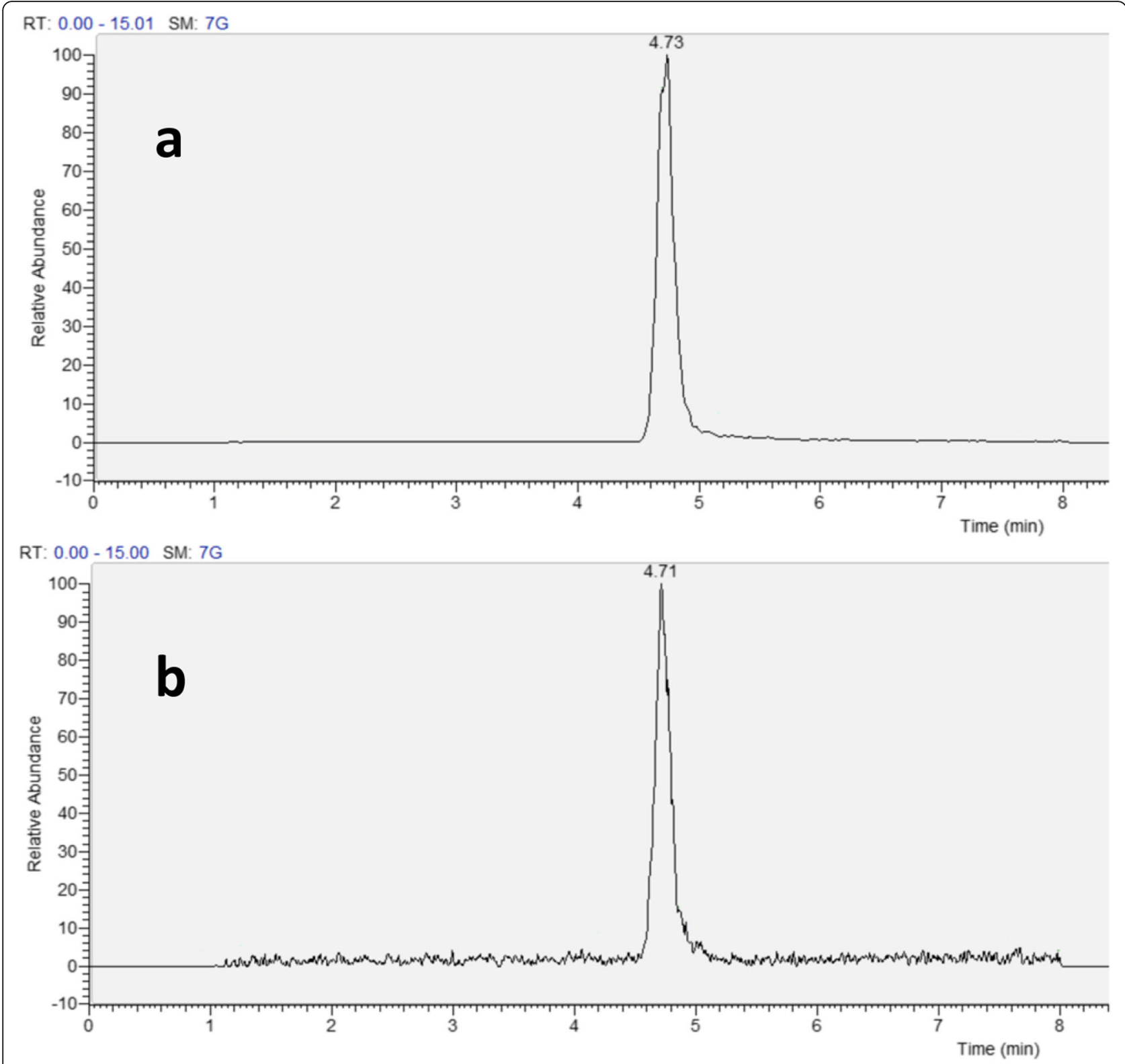

Fig. 7 Confirmation of AcAld-DNPH peak by LC/MS (extracted ion chromatogram of $m / z 223.04728[\mathrm{M}-\mathrm{H}]^{-}$). a Standard, b AcAld-DNPH peak fraction obtained by HPLC

AcAld have been analyzed as possible markers of colorectal cancer [40]. However, in those studies, only the GCMS patterns were compared between healthy people and patients, and the AcAld concentration was not monitored. Therefore, the present study is the first quantitative analysis of human fecal AcAld. Although the increase in the fecal AcAld concentration detected in this study was quite low (around $4 \mu \mathrm{M}$ ), the Meat + Wine diet showed a significantly higher level of AcAld, as compared to the Fish + Wine and Meat + Non-alcohol diets (Fig. 8). The small increase of AcAld may have occurred because the meat-rich diet in this study is within the range of a healthy diet containing vegetables and fruits, and the amounts of meat and wine were not very large; namely, $150-200 \mathrm{~g}$ meat and $120-150 \mathrm{ml}$ red wine per day. In other words, with a balanced diet containing meat, wine, vegetables, fruits and coffee, the AcAld level does not reach the minimum mutagenic concentration $(50-100 \mu \mathrm{M})$ [13].

The first pass metabolism (FPM) of ethanol to AcAld in the stomach (40-50\% of oral ethanol) before reaching the liver has been discussed [41, 42]. However, it remains difficult to explain the FPM of ethanol by enzymatic conversion, because the total ADH activity in the 


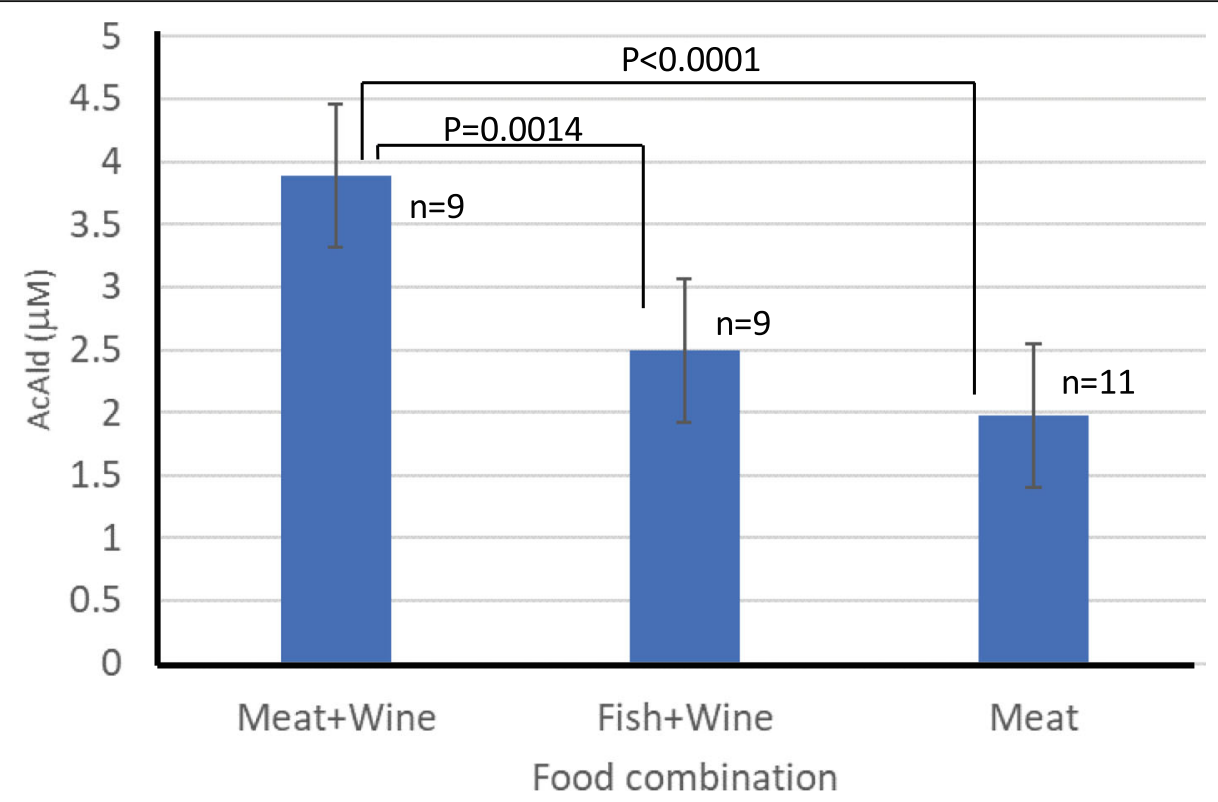

Fig. 8 Fecal AcAld levels (mean $\underline{\underline{S}} \mathrm{SD}$ ) after different dietary combinations

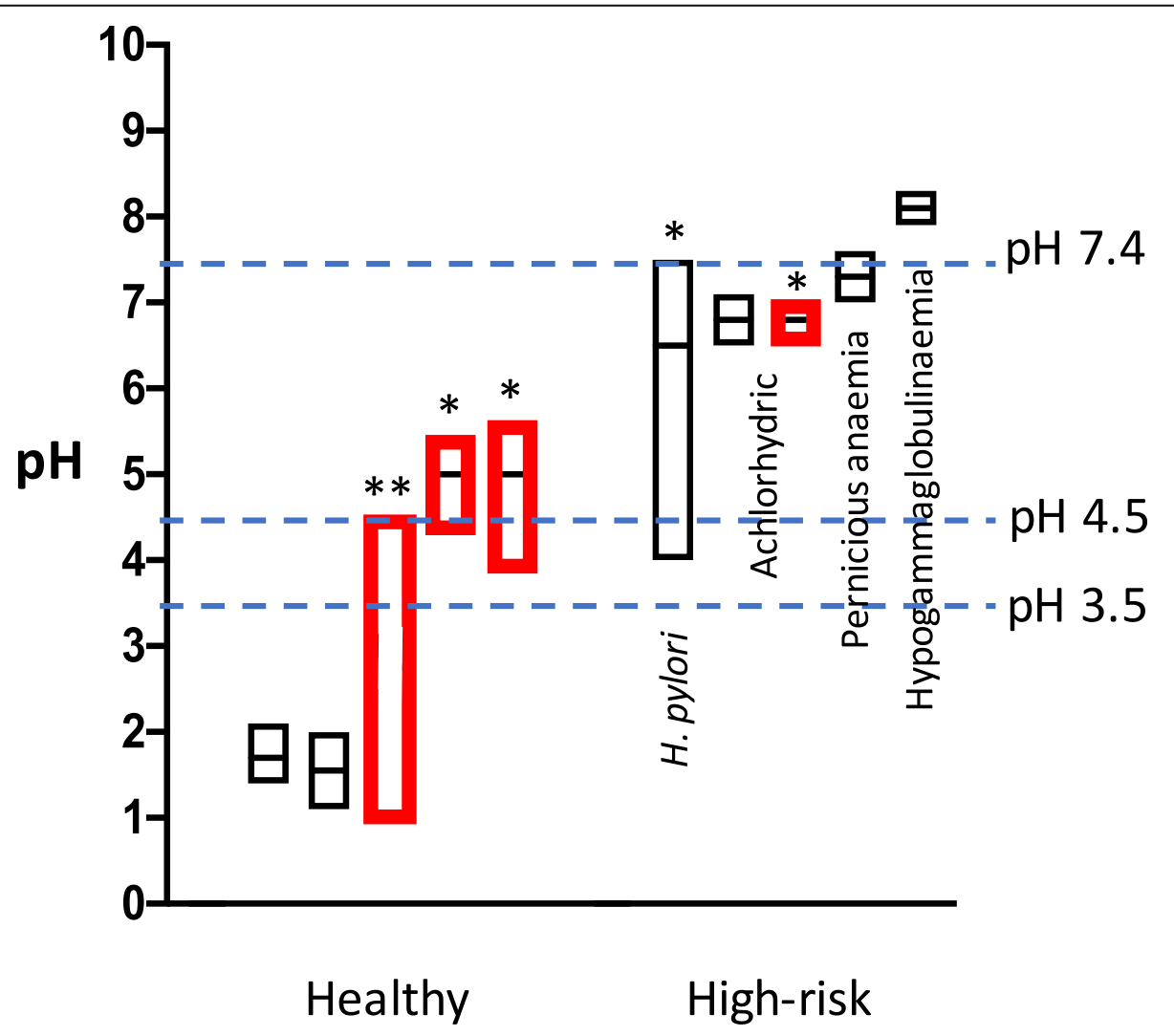

Fig. 9 Comparison of pH ranges of gastric juice between healthy and high-risk groups. Black boxes show fasted pH, and red boxes show pH after meal. Mean \pm SD are shown. *Middle bar represents median value. ${ }^{* *}$ Only $\mathrm{pH}$ range is shown 


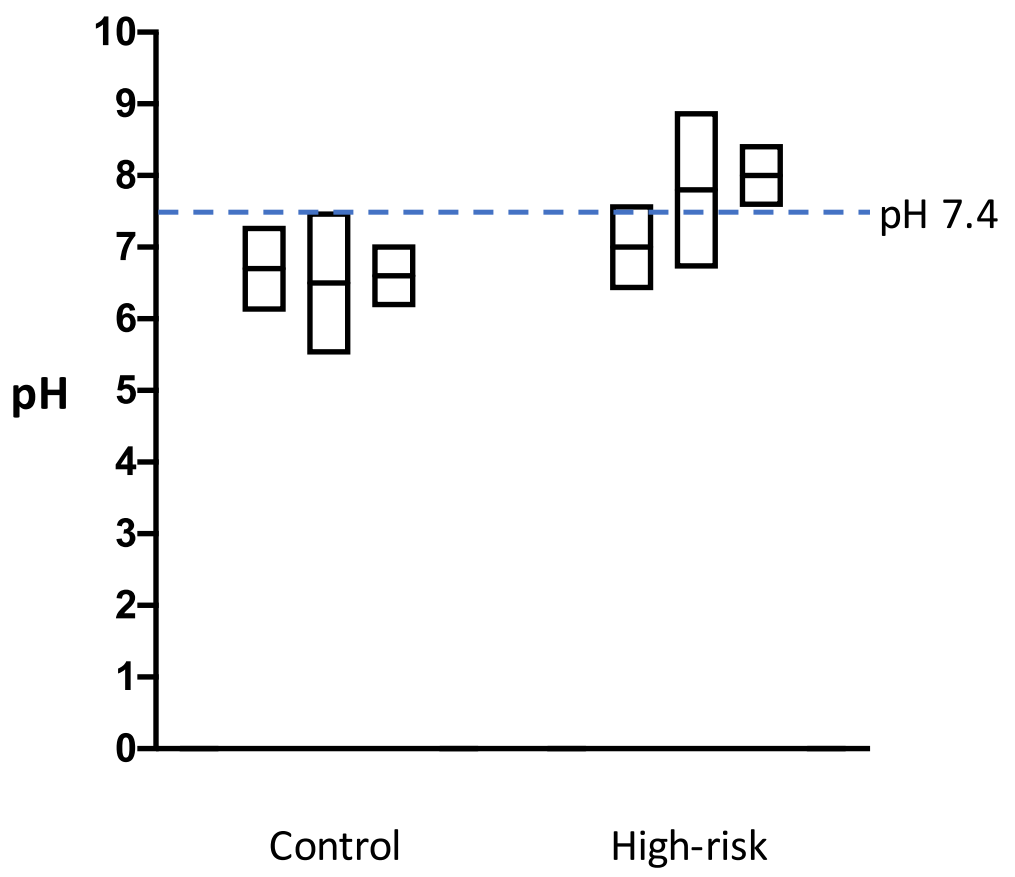

Fig. 10 Comparison of fecal pH ranges between control and colon cancer high risk groups

stomach is insufficient to account for FPM. Cortot et al. reported that enhanced alcohol disappearance $(73 \%$ of oral ethanol dose) occurs in the stomach, after a meal containing meat [43]. When alcohol was ingested orally after fasting, or by intravenous (iv) infusion, the FPM was small [44]. Therefore, the free radical-mediated mechanism of ethanol to AcAld conversion with a meat diet provides a possible answer to explain the FPM phenomenon in the stomach.

In relation to gastric cancer, these model reactions probably occur in the stomach, because the $\mathrm{pH}$ of the reaction mixture and the concentrations of $\mathrm{Mb} / \mathrm{Heme}$, wine and linoleate are comparable to those in gastric juice after a meal. In addition, the AcAld formed in gastric juice has no chance of clearance by ALDH, and may accumulate over a long period. Regarding colorectal cancer, a 13-fold greater amount of $\mathrm{OH}$ radicals is reportedly generated in human feces after a high meat and high fat diet with few vegetables, as compared to that after low meat and low fat diet with sufficient vegetables [45]. Persistant colonic ethanol, which is maintained for several hours after drinking [46, 47], may react with the $\mathrm{OH}$ radical generated in the colon to form AcAld. Therefore, the analysis of fecal AcAld levels may be a promising early marker of colon cancer risk. Further molecular epidemiological studies are required to clarify the relationships between dietary habits, such as high red meat, wine and coffee consumption, with and without fruits and vegetables, the AcAld levels in gastric juice and feces, and cancer induction.

\section{Conclusions}

Acetaldehyde (AcAld) is generated from Heme/Mb/ Meat-Linoleate-EtOH/Wine model reaction mixtures by a free radical mechanism. Depending on the conditions, such as $\mathrm{pH}$, reaction time and choice of free hemin, myoglobin $(\mathrm{Mb})$, or meat extracts (raw meat, baked meat, salami), wine and coffee enhanced AcAld formation. The fecal AcAld level was increased by the consumption of red meat with wine.

\section{Abbreviations \\ AcAld: Acetaldehyde; MLA: Methyl linoleate; Mb: Myoglobin; ADH: Alcohol dehydrogenase; ALDH: Aldehyde dehydrogenase; FPM: First pass metabolism}

\section{Acknowledgements \\ H. Kasai thanks Dr. Sugimura for discussions and encouragement throughout a collaboration on food mutagens at the National Cancer Center Research Institute from 1979 to 1982, which fostered Kasai's interest in chemical carcinogenesis.}

\section{Authors' contributions}

HK designed the study and conducted the model reactions and feces experiments. KK analyzed AcAld-DNPH by LC-MS. The two authors critically discussed the study, and read and approved the final manuscript.

Availability of data and materials

Not applicable.

\section{Declarations}

Ethics approval and consent to participate

The study was approved by the Ethics Committee of Medical Research, University of Occupational and Environmental Health, Japan (R3-005).

Consent for publication Not applicable. 


\section{Competing interests}

The authors declare that they have no competing interests.

\section{Author details}

'Department of Environmental Oncology, Institute of Industrial Ecological Sciences, University of Occupational and Environmental Health, 1-1 Iseigaoka, Yahatanishi-ku, Fukuoka 807-8555 Kitakyushu, Japan. ${ }^{2}$ Center for Stress-related Disease Control and Prevention, University of Occupational and Environmental Health, 1-1 Iseigaoka, Yahatanishi-ku, Fukuoka 807-8555 Kitakyushu, Japan.

\section{Received: 21 May 2021 Accepted: 27 June 2021}

\section{Published online: 09 July 2021}

\section{References}

1. Na HK, Lee JY. Molecular basis of alcohol-related gastric and colon cancer. Int J Mol Sci. 2017;18(6):1116.

2. Bonequi P, Meneses-Gonzalez F, Correa P, Rabkin CS, Camargo MC. Risk factors for gastric cancer in Latin America: a meta-analysis. Cancer Causes Control. 2013;24(2):217-31.

3. Vieira AR, Abar L, Chan DSM, Vingeliene S, Polemiti E, Stevens C, et al. Foods and beverages and colorectal cancer risk: a systematic review and metaanalysis of cohort studies, an update of the evidence of the WCRF-AICR Continuous Update Project. Ann Oncol. 2017;28(8):1788-802.

4. Birt DF, Phillips GJ. Diet, genes, and microbes: complexities of colon cancer prevention. Toxicol Pathol. 2014;42(1):182-8.

5. Ngoan LT, Mizoue T, Fujino Y, Tokui N, Yoshimura T. Dietary factors and stomach cancer mortality. Br J Cancer. 2002;87(1):37-42.

6. Somi MH, Mousavi SM, Naghashi S, Faramarzi E, Jafarabadi MA, Ghojazade $\mathrm{M}$, et al. Is there any relationship between food habits in the last two decades and gastric cancer in North-Western Iran? Asian Pac J Cancer Prev. 2015;16(1):283-90.

7. Lin J, Zhang SM, Cook NR, Lee IM, Buring JE. Dietary fat and fatty acids and risk of colorectal cancer in women. Am J Epidemiol. 2004;160(10):1011-22.

8. Greenblatt MS, Bennett WP, Hollstein M, Harris CC. Mutations in the p53 tumor suppressor gene: clues to cancer etiology and molecular pathogenesis. Cancer Res. 1994;54(18):4855-78.

9. Paget $V$, Lechevrel M, Sichel F. Acetaldehyde-induced mutational pattern in the tumour suppressor gene TP53 analysed by use of a functional assay, the FASAY (functional analysis of separated alleles in yeast). Mutat Res. 2008; 652(1):12-9.

10. Paget $\mathrm{V}$, Lechevrel $M$, Andre $\mathrm{V}$, Goff JL, Pottier D, Billet $\mathrm{S}$, et al. Benzo[a]pyrene, aflatoxine $B_{1}$ and acetaldehyde mutational patterns in TP53 gene using a functional assay: relevance to human cancer aetiology. PLoS One. 2012;7(2):e30921.

11. Kasai $\mathrm{H}$. What causes human cancer? Approaches from the chemistry of DNA damage. Genes Environ. 2016;38:19.

12. Kasai H, Kawai K. New plausible mechanism for gastric and colorectal carcinogenesis: Free radical-mediated acetaldehyde generation in a heme/myoglobin-linoleate-ethanol mixture. ACS Omega. 2021;6(18): 12014-21.

13. Lachenmeier DW, Monakhova YB. Short-term salivary acetaldehyde increase due to direct exposure to alcoholic beverages as an additional cancer risk factor beyond ethanol metabolism. J Exp Clin Cancer Res. 2011;30:3.

14. IARC Working Group on the Evaluation of Carcinogenic Risks to Human. Volume 100 E. A review of human carcinogens. IARC Monogr Eval Carcinog Risks Hum. 2012;100(Pt E):1-538.

15. Bastide NM, Pierre FH, Corpet DE. Heme iron from meat and risk of colorectal cancer: a meta-analysis and a review of the mechanisms involved. Cancer Prev Res (Phila). 2011;4(2):177-84.

16. Amor $S$, Chalons $P$, Aires $V$, Delmas D. Polyphenol extracts from red wine and grapevine: Potential effects on cancers. Diseases. 2018;6(4):106.

17. Hoey J, Montvernay C, Lambert R. Wine and tobacco: risk factors for gastric cancer in France. Am J Epidemiol. 1981;113(6):668-74.

18. Falcao JM, Dias JA, Miranda AC, Leitao CN, Lacerda MM, da Motta LC. Red wine consumption and gastric cancer in Portugal: a case-control study. Eur J Cancer Prev. 1994;3(3):269-76.

19. De Stefani E, Correa P, Fierro L, Carzoglio J, Deneo-Pellegrini H, Zavala D. Alcohol drinking and tobacco smoking in gastric cancer. A case-control study. Rev Epidemiol Sante Publique. 1990;38(4):297-307.
20. Klatsky AL, Armstrong MA, Friedman GD, Hiatt RA. The relations of alcoholic beverage use to colon and rectal cancer. Am J Epidemiol. 1988;128(5):1007-15.

21. Ferrari $P$, Jenab M, Norat $T$, Moskal $A$, Slimani $N$, Olsen $A$, et al. Lifetime and baseline alcohol intake and risk of colon and rectal cancers in the European prospective investigation into cancer and nutrition (EPIC). Int J Cancer. 2007; 121(9):2065-72

22. Lee DH, Anderson KE, Harnack LJ, Folsom AR, Jacobs DR Jr. Heme iron, zinc, alcohol consumption, and colon cancer: lowa Women's Health Study. J Natl Cancer Inst. 2004:96(5):403-7.

23. Larsson SC, Adami HO, Giovannucci E, Wolk A. Re: Heme iron, zinc, alcohol consumption, and risk of colon cancer. J Natl Cancer Inst. 2005;97(3):232-3 author reply 3-4.

24. Zeng $S B$, Weng $H$, Zhou M, Duan XL, Shen XF, Zeng XT. Long-term coffee consumption and risk of gastric cancer: A PRISMA-compliant dose-response meta-analysis of prospective cohort studies. Medicine. 2015;94(38):e1640.

25. Shen Z, Liu H, Cao H. Coffee consumption and risk of gastric cancer: an updated meta-analysis. Clin Res Hepatol Gastroenterol. 2015:39(2):245-53.

26. Yamada H, Kawado M, Aoyama N, Hashimoto S, Suzuki K, Wakai K, et al. Coffee consumption and risk of colorectal cancer: the Japan collaborative cohort study. J Epidemiol. 2014;24(5):370-8.

27. Huxley RR, Ansary-Moghaddam A, Clifton P, Czernichow S, Parr CL, Woodward M. The impact of dietary and lifestyle risk factors on risk of colorectal cancer: a quantitative overview of the epidemiological evidence. Int J Cancer. 2009;125(1):171-80.

28. Russell TL, Berardi RR, Barnett JL, Dermentzoglou LC, Jarvenpaa KM, Schmaltz SP, et al. Upper gastrointestinal pH in seventy-nine healthy, elderly, North American men and women. Pharm Res. 1993;10(2):187-96.

29. Dressman JB, Berardi RR, Dermentzoglou LC, Russell TL, Schmaltz SP, Barnett $J$, et al. Upper gastrointestinal (Gl) pH in young, healthy men and women. Pharm Res. 1990;7(7):756-61.

30. Furuta T, Baba S, Takashima M, Futami H, Arai H, Kajimura M, et al. Effect of Helicobacter pylori infection on gastric juice pH. Scand J Gastroenterol. 1998; 33(4):357-63.

31. Borriello SP, Reed PJ, Dolby JM, Barclay FE, Webster AD. Microbial and metabolic profile of achlorhydric stomach: comparison of pernicious anaemia and hypogammaglobulinaemia. J Clin Pathol. 1985;38(8):946-53.

32. Gardner JD, Ciociola AA, Robinson M. Measurement of meal-stimulated gastric acid secretion by in vivo gastric autotitration. J Appl Physiol (1985). 2002;92(2):427-34

33. Gonzalez CA, Riboli E. Diet and cancer prevention: where we are, where we are going. Nutr Cancer. 2006;56(2):225-31

34. Gonzalez CA, Lopez-Carrillo L. Helicobacter pylori, nutrition and smoking interactions: their impact in gastric carcinogenesis. Scand J Gastroenterol. 2010:45(1):6-14.

35. Samelson SL, Nelson RL, Nyhus LM. Protective role of faecal pH in experimental colon carcinogenesis. J R Soc Med. 1985;78(3):230-3.

36. Bayliak MM, Burdyliuk NI, Lushchak VI. Effects of $\mathrm{pH}$ on antioxidant and prooxidant properties of common medicinal herbs. Open Life Sci. 2016; 11(1):298-307.

37. Tsuruya A, Kuwahara A, Saito Y, Yamaguchi H, Tenma N, Inai M, et al. Major anaerobic bacteria responsible for the production of carcinogenic acetaldehyde from ethanol in the colon and rectum. Alcohol Alcohol. 2016;51(4):395-401.

38. Cueva C, Silva M, Pinillos I, Bartolomé B, Moreno-Arribas M. Interplay between dietary polyphenols and oral and gut microbiota in the development of colorectal cancer. Nutrients. 2020;12(3):625.

39. Garner CE, Smith S, de Lacy Costello B, White P, Spencer R, Probert CS, et al. Volatile organic compounds from feces and their potential for diagnosis of gastrointestinal disease. FASEB J. 2007;21(8):1675-88.

40. Arasaradnam RP, McFarlane MJ, Ryan-Fisher C, Westenbrink E, Hodges $P$, Thomas MG, et al. Detection of colorectal cancer (CRC) by urinary volatile organic compound analysis. PLoS One. 2014;9(9):e108750.

41. Zakhari S. Overview: how is alcohol metabolized by the body? Alcohol Res Health. 2006;29(4):245

42. Crabb DW. First pass metabolism of ethanol: gastric or hepatic, mountain or molehill? Hepatology. 1997;25(5):1292-4.

43. Cortot A, Jobin G, Ducrot F, Aymes C, Giraudeaux V, Modigliani R. Gastric emptying and gastrointestinal absorption of alcohol ingested with a meal. Dig Dis Sci. 1986;31(4):343-8.

44. Jones AW, Jonsson KA, Kechagias S. Effect of high-fat, high-protein, and high-carbohydrate meals on the pharmacokinetics of a small dose of ethanol. Br J Clin Pharmacol. 1997;44(6):521-6. 
45. Erhardt JG, Lim SS, Bode JC, Bode C. A diet rich in fat and poor in dietary fiber increases the in vitro formation of reactive oxygen species in human feces. J Nutr. 1997;127(5):706-9.

46. Jokelainen K, Matysiak-Budnik T, Makisalo H, Hockerstedt K, Salaspuro M. High intracolonic acetaldehyde values produced by a bacteriocolonic pathway for ethanol oxidation in piglets. Gut. 1996;39(1):100-4.

47. Halsted $\mathrm{CH}$, Robles EA, Mezey E. Distribution of ethanol in the human gastrointestinal tract. Am J Clin Nutr. 1973;26(8):831-4.

\section{Publisher's Note}

Springer Nature remains neutral with regard to jurisdictional claims in published maps and institutional affiliations.

Ready to submit your research? Choose BMC and benefit from:

- fast, convenient online submission

- thorough peer review by experienced researchers in your field

- rapid publication on acceptance

- support for research data, including large and complex data types

- gold Open Access which fosters wider collaboration and increased citations

- maximum visibility for your research: over $100 \mathrm{M}$ website views per year

At $\mathrm{BMC}$, research is always in progress.

Learn more biomedcentral.com/submissions 